\title{
Pomiary rozkładów dawek poza obszarem terapeutycznym na wybranych głębokościach i odległościach od osi wiązki.
}

\section{Measurements of peripheral dose in a water phantom for different distances and depths}

\author{
A.Kowalik ${ }^{1}$, W.Jackowiak ${ }^{2}$, M. Kruszyna ${ }^{1}$, S. Adamczyk ${ }^{1}$, \\ M. Skórska ${ }^{1}$, W. Suchorska ${ }^{3}$, K. Zaleska ${ }^{3}$, J. Malicki ${ }^{1}$ \\ ${ }^{1}$ Medical Physics Department, Greater Poland Cancer Center, Poznan, Poland, \\ ${ }^{2}$ Radiotherapy Department I, Greater Poland Cancer Center, Poznan, Poland, \\ ${ }^{3}$ Radiobiology Laboratory, Greater Poland Cancer Center, Poznan, Poland.
}

\section{Streszczenie}

Celem pracy było zbadanie dawek poza obszarem terapeutycznym na wybranych głębokościach i odległościach od osi wiązki (CAX). Na potrzeby badania zaprojektowano i skonstruowano fantom wodny o wymiarach $45 \mathrm{~cm}$ x $35 \mathrm{~cm}$ x $90 \mathrm{~cm}$, w którym umieszczone zostały detektory termoluminescencyjne (TLD 100). Detektory umiejscowiono na czterech głębokościach : $2 \mathrm{~cm}, 5 \mathrm{~cm}, 8 \mathrm{~cm}$ i $15 \mathrm{~cm}$ oraz czterech odległościach (dla każdej głębokości) od osi wiązki: $10 \mathrm{~cm}, 20 \mathrm{~cm}, 30 \mathrm{~cm}$ i $40 \mathrm{~cm}$. W osi wiązki zadano dawkę 76 Gy, co odpowiadało 7503 jednostkom monitorowym (MU). Dawka w odległości $10 \mathrm{~cm}$ od osi wiązki i 2 cm głębokości była bliska dawce na głębokości $15 \mathrm{~cm}$ i wynosiła średnio 2,3 Gy. Pomiary pokazały silną zależność dawki w zależności od odległości od osi wiązki. Dla dystansu $40 \mathrm{~cm}$ od CAX na głębokości $2 \mathrm{~cm}$, zmierzono dawkę równą 0,27 Gy (SD = 0,025 Gy), na $15 \mathrm{~cm}$ od CAX 0,116 Gy (SD = 0,066 Gy). W odległości $30 \mathrm{~cm}$ od osi wiązki zależność dawki wraz z głębokością była znacząca na głębokości $2 \mathrm{~cm}$ - 0,524 Gy (SD = 0,251 Gy) oraz na głębokości $15 \mathrm{~cm}-0,242 \mathrm{~Gy}(\mathrm{SD}=0,564 \mathrm{~Gy}) .20 \mathrm{~cm}$ od osi wiązki na głębokości $2 \mathrm{~cm}$ wynosiła 0,925 Gy (SD = 0,483 Gy) a na głębokości 15 cm 0,517 Gy (SD = 0,160 Gy).

\footnotetext{
Abstract

Adres do korespondencji

Anna Kowalik

Zakład Fizyki Medycznej,

Wielkopolskie Centrum Onkologii, ul. Garbary 15, 61-866 Poznań, Polska

Telefon. +48605 318115

e-mail: annakowalik@poczta.onet.pl
}

The aim of this study was to check the doses outside the therapeutic region at different distances and depths.For the measurements there was designed and created the special water phantom of the size $40 \mathrm{~cm}$ 
x $35 \mathrm{~cm}$ x $90 \mathrm{~cm}$. In the phantom were located inserts with PMMA slabs with TLD 100 chips inside. The inserts were deployed in five depths: $2 \mathrm{~cm}, 5 \mathrm{~cm}, 8 \mathrm{~cm}$ and $15 \mathrm{~cm}$ and $10 \mathrm{~cm}, 20 \mathrm{~cm}, 30 \mathrm{~cm}, 40 \mathrm{~cm}$ from the CAX. The results for distance from CAX $10 \mathrm{~cm}$ show that the dose on the depth $2 \mathrm{~cm}$ was quite the same that in the depth $15 \mathrm{~cm}$ and it was about $2.3 \mathrm{~Gy}$. Measurements show that the strong dependence of the dose we observed far away from the CAX. For the distance $40 \mathrm{~cm}$ for the depth $2 \mathrm{~cm}$ the dose was $0.27 \mathrm{~Gy}(\mathrm{SD}=0.025$ Gy) and on $15 \mathrm{~cm}$ was $0.116 \mathrm{~Gy}(\mathrm{SD}=0.066 \mathrm{~Gy})$, it is about $50 \%$ lower. For the distance $30 \mathrm{~cm}$ the dependence from depth was also significant for the depth $2 \mathrm{~cm}-0.524 \mathrm{~Gy}(\mathrm{SD}=0.251 \mathrm{~Gy})$ and for $15 \mathrm{~cm}-0.242 \mathrm{~Gy}$ (SD $=0.564 \mathrm{~Gy}$ ). On distance $20 \mathrm{~cm}$ the dose on the depth $2 \mathrm{~cm}$ was $0.925 \mathrm{~Gy}(\mathrm{SD}=0.483 \mathrm{~Gy})$ and on depth $15 \mathrm{~cm}$ $(\mathrm{SD}=0.160 \mathrm{~Gy})$. We found that the dose differ little between each depth and fall rapidly with distance from the central axis beam. As you would expect biggest decline dose was between $10 \mathrm{~cm}$ and $20 \mathrm{~cm}$ from the axis (the area penumbra). The highest out of field doses were measured for a distance of $10 \mathrm{~cm}$ on all depths and the smallest for $40 \mathrm{~cm}$.

Stowa kluczowe: radioterapia, niskie dawki, dawki poza polem terapeutycznym, promieniowanie rozproszone, dozymetria termoluminescencyjna

Keywords: radiotherapy, low doses, out-of-field dose, scatter radiation, TLD dosimetry

\section{Wstęp}

Obecnie niemal 50\% wszystkich pacjentów chorych na nowotwory jest leczonych z wykorzystaniem promieniowania jonizującego. Ciągły rozwój metod radioterapii stawia coraz większe wymagania względem stosowanego sprzętu terapeutycznego. Nowoczesne technologie, zaczynając od akceleratorów liniowych cząstek naładowanych poprzez techniki intensywnej modulacji dawki - IMRT (ang IMRT - Intesity Modulated Radiation Therapy), technikę sterowaną obrazem - IGRT (ang. IGRT - Image - Guided Radiation Therapy) czy terapię helikalną (Tomoterapia), umożliwiają uzyskanie bardziej konformalnych rozkładów dawek w guzie nowotworowym. Następstwem konformalizacji dawek w objętości guza jest ograniczenie dawek w narządach krytycznych. Rozwój nowoczesnych metod leczenia wiąże się również z wprowadzeniem nowych technik w radioterapii co umożliwia podniesienie dawki w objętości guza z jednoczesnym zachowaniem dużego gradientu dawki poza objętością napromienianą. Wszystkie plany leczenia są zoptymalizowane w celu zapewnienia jak najmniejszej dawki w narządach krytycznych oraz zdrowych tkankach. Opracowano wiele algorytmów planowania w celu dokładnego obliczenia dawki w obszarze guza, natomiast dawki poza polem nadal są obiektem badań [1-5]. Współcześnie techniki radioterapii, takie jak: 3DCRT ( 3DCRT - 3D Conformal Radiation Therapy), IMRT i terapia protonowa w porównaniu do wcześniejszych metod, zapewniają lepszą homogenność dawki w obszarze guza i niższe dawki dla narządów krytycznych. Odbywa się to jednak kosztem większej dawki w narządach odległych ze względu na: zastosowanie wyższej energii, dłuższego czasu napromieniania oraz występowania promieniowania neutronowego [8,9]. Autorzy A. Kowalik i współpracownicy przeprowadzili w 2012 r. badanie pomiaru dawki w fantomie antropomorficznym w wybranych narządach krytycznych, takich jak płuca, tarczyca, pęcherz moczowy i jądra za pomocą trzech technik napromieniowania raka prostaty: 3DCRT, IMRT i Tomoterapii [8]. W badaniu do pomiaru wykorzystano fantom antropomorficzny Aldersona oraz detektory termoluminescencyjne (TLD 100, Harshaw) zbudowane z 6Li (7,5\%) i $7 \mathrm{Li}(92,5 \%)$. Zmierzono także komponentę promieniowania neutronowego w wybranych punktach, używając złotych folii (o,5 cm średnicy, średnia gęstość o,108 g/cm3). Otrzymano następujące wyniki dla poszczególnych technik napromieniania (3DCRT, IMRT, Tomoterapia): tarczyca

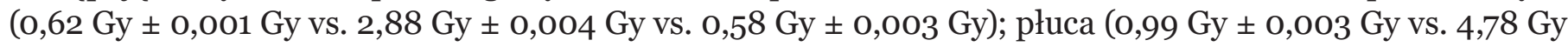
\pm 0,006 Gy vs. 0,67 Gy \pm 0,003 Gy); pęcherz (80,61 Gy \pm 0,054 Gy vs. 53,75 Gy \pm 0,070 Gy vs. 34,71 Gy \pm

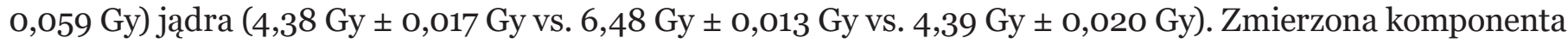
promieniowania neutronowego wynosiła 0.5\% dawki dla PTV. Problem niskich dawek podjęli w swojej pracy również M. Rafi Uddin [9] i R. Kaderka i in. [10]. Autorzy wykazali, że dawka poza PTV mieści się w zakresie od $5 \%$ do $36 \%$ dawki w osi wiązki. 


\section{Cel}

Celem badania były pomiary rozkładów dawek poza obszarem terapeutycznym na wybranych głębokościach i odległościach od osi wiązki.

\section{Materiał i metoda}

W celu przeprowadzenia pomiarów, zaprojektowano i wykonano specjalny fantom wodny o wymiarach $40 \mathrm{~cm}$ x $35 \mathrm{~cm}$ x $90 \mathrm{~cm}$ (Ryc. 1), w którym umieszczone zostały, w wodoszczelnych bloczkach wykonanych $\mathrm{z}$ pleksi detektory termoluminescencyjne. Do pomiarów wykorzystano detektory termoluminescencyjne TL10o firmy Harshaw, które mają postać spieków z fluorku litu (LiF) o wymiarach 3,0 mm x 3,0 mm x 0,9 mm. Istotą działania detektorów jest magazynowanie części energii pochłoniętej w czasie przechodzenia przez nie promieniowania jonizującego. W wyniku podgrzewania próbki następuje przenoszenie elektronów z pułapek elektronowych do wyższych poziomów, skąd następnie wracają do poziomu podstawowego emitując energię w postaci światła. Ilość energii zaabsorbowanej przez detektor, która jest emitowana w postaci światła, jest proporcjonalna do liczby elektronów w pułapkach elektronowych, co odpowiada energii zaabsorbowanej podczas napromieniania. Odczyt zaabsorbowanego ładunku odbywa się w czytniku detektorów termoluminescencyjnych, składającego się z grzejnika, fotopowielacza przetwarzającego małą ilość światła na impuls prądowy, układu liczącego oraz mikroprocesora do przetwarzania impulsów. Po odczycie detektor zostaje poddany obróbce termicznej, w celu przygotowania go do następnej ekspozycji. Czułość detektora termoluminescencyjnego nie jest stała, dlatego też niezbędne jest wykonanie kalibracji w odpowiednich warunkach, co pozwala na wyznaczenie współczynnika kalibracyjnego.

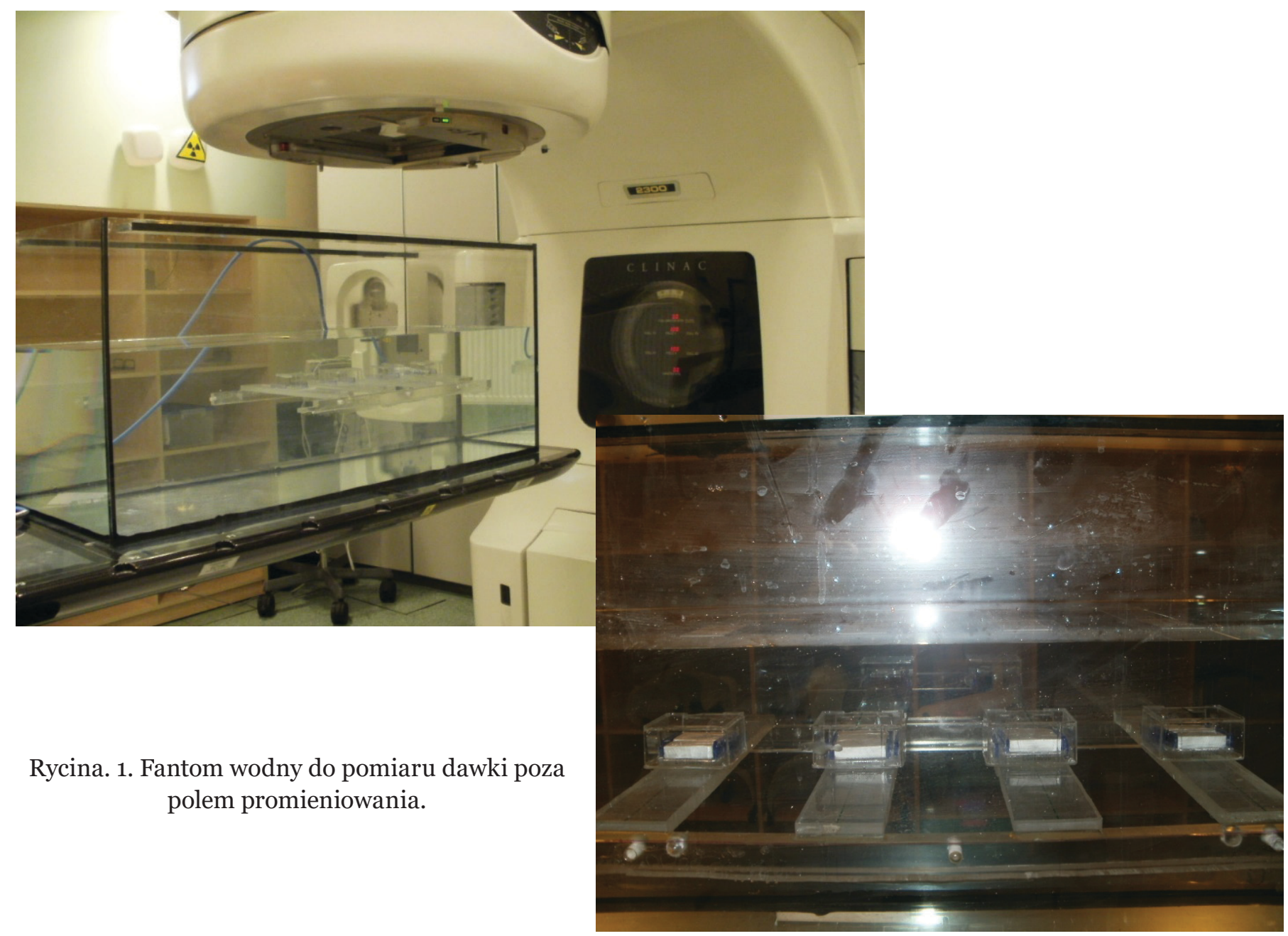


Detektory rozmieszczone były na czterech głębokościach: $2 \mathrm{~cm}, 5 \mathrm{~cm}, 8 \mathrm{~cm}$ i $15 \mathrm{~cm}$ oraz czterech odległościach od osi wiązki: $10 \mathrm{~cm}, 20 \mathrm{~cm}, 30 \mathrm{~cm}$ i $40 \mathrm{~cm}$ (Rycina 2).

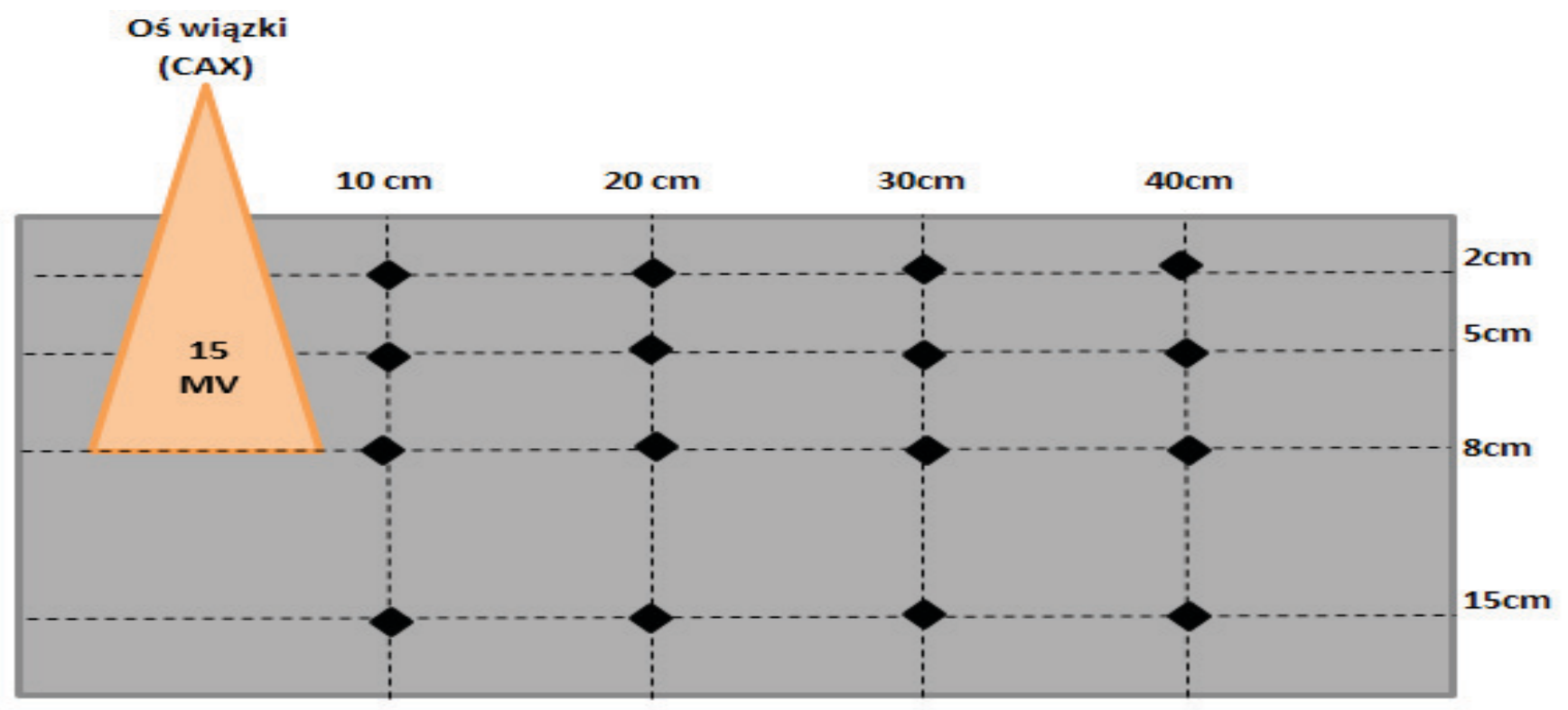

punkt pomiarowy

Rycina 2. Schemat układu pomiarowego

Detektory termoluminescencyjne zostały poddane kalibracji w specjalnym fantomie wykonanym z pleksi. $\mathrm{Na}$ skanach tomograficznych określono parametry napromieniania. Przygotowano trójwymiarowy plan leczenia uwzględniający kontury detektorów TLD, umieszczonych wewnątrz fantomu. Odległość od źródła do powierzchni fantomu (SSD- Source Skin Distance) wynosiła $100 \mathrm{~cm}$, energia 15 MV oraz dawka 0,5 Gy. Tak przygotowane detektory napromieniano na akceleratorze liniowym. W celu ustabilizowania sygnału po napromienieniu poddawano je procesowi podgrzania w specjalnym czytniku ( Harshaw TLD Reader, model 3500). Podczas odczytu detektorów wykorzystany został gaz - w celu zapewnienia jak największej dokładności odczytu, tak ważnej w przypadku badania niskich dawek. Do odczytu zastosowano program WinREMS Bicron (Harshaw, wersja PL-26732.8.2.1.0). Odczytu dokonywano 24 godziny po napromienianiu. Pomiary kalibracyjne powtórzono dziesięć razy, następnie obliczono współczynniki kalibracyjne detektorów i współczynniki zmienności danego detektora. Po każdym odczycie detektory poddawane były procesowi anilacji sygnału detektora przy pomocy wysokiej temperatury.

Następnie przygotowano plan leczenia $\mathrm{w}$ technice izocentrycznej z pól symulujących leczenie pacjenta: pole $10 \mathrm{~cm}$ x $10 \mathrm{~cm}$, energia $15 \mathrm{MV}$, dose rate $600 \mathrm{MU} / \mathrm{min}$. Dawkę normalizowano na punkt na głębokości $8 \mathrm{~cm}$. W osi wiązki podano dawkę $76 \mathrm{~Gy}$, co odpowiadało 7503 jednostkom monitorowym (MU) w jednej frakcji. Plan leczenia obliczono w komputerowym systemie planowania leczenia - Eclipse Treatment Planning System, Varian, Version 13.6. Pomiary zostały wykonane detektorami termoluminescencyjnymi typu 100 (TLD 100) składającymi się z 7,5\% $6 \mathrm{Li}$ i 92,5\% 7 Li.

Każdemu powtórzeniu pomiarów towarzyszył ten sam schemat przygotowania fantomu i detektorów. Przed rozpoczęciem napromieniania, fantom był każdorazowo pozycjonowany na stole terapeutycznym w oparciu o markery obecne na ścianie fantomu, następnie umieszczano detektory TL i sprawdzano poziom wody. Dawka w osi wiązki była weryfikowano przy pomocy komory jonizacyjnej typu Farmer (PTW Freiburg, nr seryjny 3535) i dawkomierza PTW Unidos (PTW Freiburg, nr seryjny E80610). Detektory termoluminescencyjne umieszczone były prostopadle do osi wiązki. W celu zapewnienia ochrony przed wodą wykorzystano parafilm, którym zabezpieczono bloczki z TLD. Pojedyncza sesja napromieniania trwała około 13 minut.

Procedura odczytu detektorów termoluminescencyjnych wykorzystana w badaniu była taka sama jak 
w przypadku kalibracji. Wykorzystano również dodatkowe detektory TL, umieszczone w sterowni podczas napromieniania, których zadaniem był pomiar promieniowania tła.

\section{Wyniki}

W pierwszym etapie analizie poddano zależność dawki od odległości od osi wiązki. Wyniki przedstawiono w tabeli nr 1.

\begin{tabular}{|c|c|c|c|}
\hline Odległość od osi wiązki [cm] & Glębokość [cm] & $\begin{array}{l}\text { Średnia dawka } \\
\text { zmierzona [Gy] }\end{array}$ & \pm SD [Gy] \\
\hline \multirow{4}{*}{10} & 2 & 2,354 & 0,864 \\
\hline & 5 & 2,345 & 0,059 \\
\hline & 8 & 2,254 & 0,074 \\
\hline & 15 & 2,351 & 0,164 \\
\hline \multirow{4}{*}{20} & 2 & 0,925 & 0,106 \\
\hline & 5 & 1,202 & 0,483 \\
\hline & 8 & 0,716 & 0,424 \\
\hline & 15 & 0,517 & 0,160 \\
\hline \multirow{4}{*}{30} & 2 & 0,524 & 0,251 \\
\hline & 5 & 0,258 & 0,964 \\
\hline & 8 & 0,349 & 0,223 \\
\hline & 15 & 0,242 & 0,564 \\
\hline \multirow{4}{*}{40} & 2 & 0,270 & 0,025 \\
\hline & 5 & 0,305 & 0,266 \\
\hline & 8 & 0,222 & 0,203 \\
\hline & 15 & 0,116 & 0,066 \\
\hline
\end{tabular}

Tabela 1. Zależność dawki od odległości od osi wiązki (CAX).

Wyniki pomiaru dawki w odległości $10 \mathrm{~cm}$ od osi wiązki na głębokości $2 \mathrm{~cm}$ były porównywalne z dawką na głębokości $15 \mathrm{~cm}$ i wynosiły średnio 2,3 Gy (przyp. 76 Gy podawano w osi wiązki). Pomiary wykazują wysoką zależność wartości dawki wraz ze wzrostem odległości od osi wiązki. Dla dystansu $40 \mathrm{~cm}$ i głębokości $2 \mathrm{~cm}$ dawka wynosiła 0,27 Gy (SD = 0,025 Gy), a na głębokości $15 \mathrm{~cm}$ wynosiła 0,116 Gy (SD = 0,066 Gy) i była o 50\% mniejsza w porównaniu do dawki na głębokości $2 \mathrm{~cm}$. Dla dystansu $30 \mathrm{~cm}$ od CAX zależność dawki od głębokości była znacząca również na głębokości $2 \mathrm{~cm}$ i $15 \mathrm{~cm}$ wynosiła odpowiednio 0,524 Gy (SD = 0,251 Gy) i 0,242 Gy (SD = 0,483 Gy). Na odległości $20 \mathrm{~cm}$ od osi wiązki i głębokości $2 \mathrm{~cm}$ dawka wyniosła 0,925 Gy (SD = 0,106 Gy) a dla głębokości $15 \mathrm{~cm} \mathrm{0,517} \mathrm{Gy} \mathrm{(SD} \mathrm{=} \mathrm{0,160} \mathrm{Gy).}$

Na rycinach $3-6$ przedstawione zostały wyniki prezentujące zależność dawki od głębokości i odległości od osi wiązki.

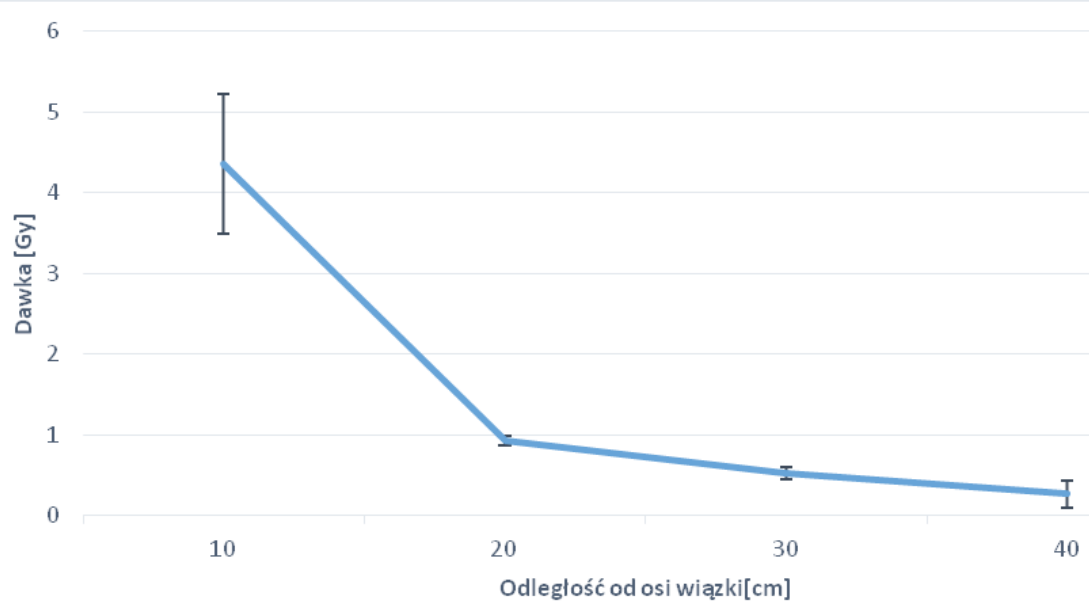

Rycina 3. Zleżność rozkładu dawki od odległości od osi wiązki na głębokości $2 \mathrm{~cm} \mathrm{w}$ fantomie wodnym. 
Rycina 3 przedstawia wartości dawek na głębokości $2 \mathrm{~cm}$ dla każdego dystansu pomiarowego. Obserwowany był szybki spadek dawki pomiędzy $10 \mathrm{~cm}$ a $20 \mathrm{~cm}$ od osi wiązki w porównaniu z większą stabilnością dawki między 20 $\mathrm{cm}, 30 \mathrm{~cm}$ a $40 \mathrm{~cm}$ od CAX. Jak przedstawiono w Tabeli 1, dawka na głębokości $2 \mathrm{~cm}$ i $10 \mathrm{~cm}$ głębokości wyniosła 2,354 Gy i stanowiła blisko 40\% dawki zadanej w osi.

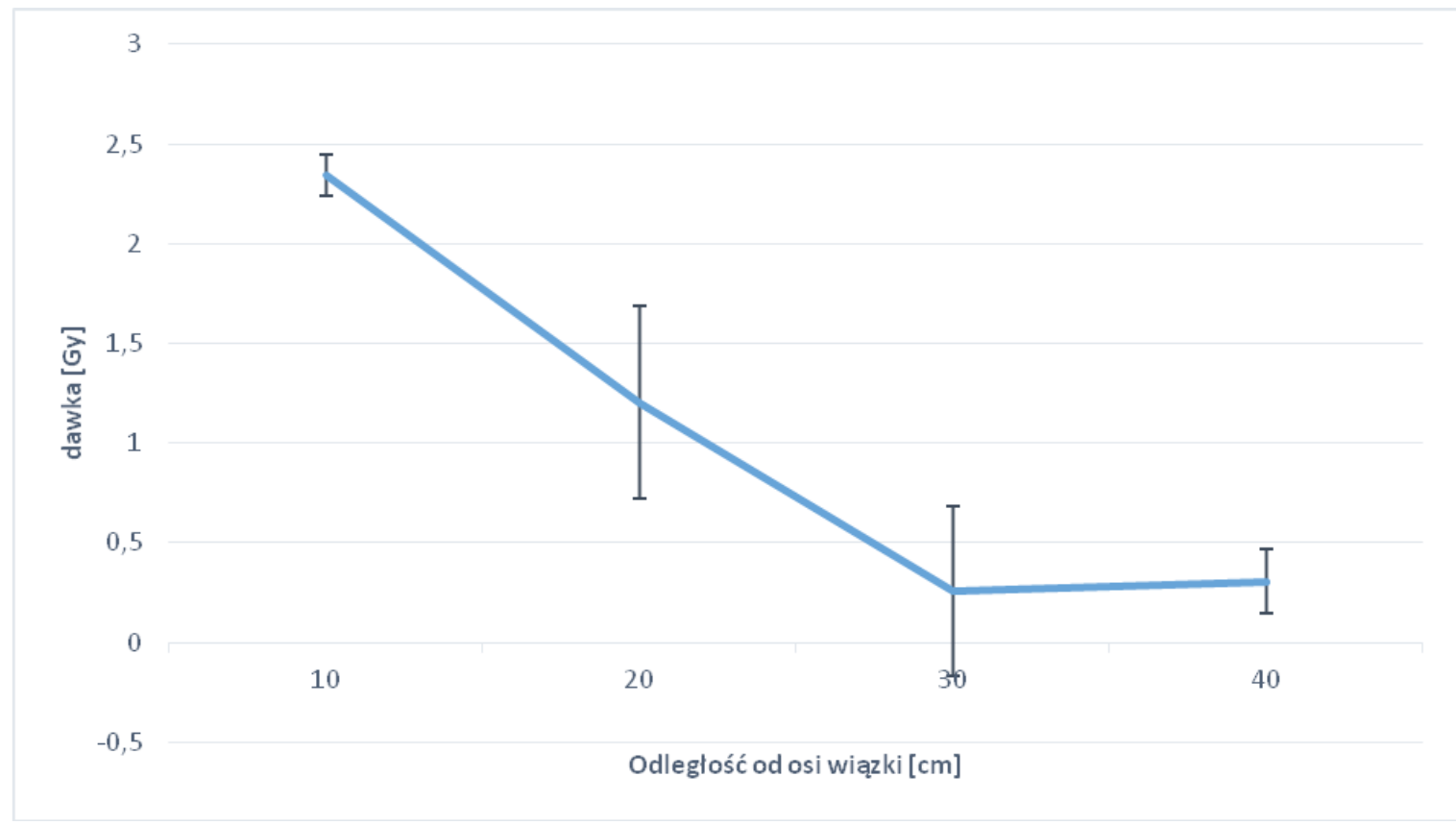

Rycina 4. Zleżność rozkładu dawki od odległości od osi wiązki na głębokości $5 \mathrm{~cm} \mathrm{w}$ fantomie wodnym.

Dla głębokości $5 \mathrm{~cm}$ obserwowany był szybki spadek dawki pomiędzy $10 \mathrm{~cm}$ a $30 \mathrm{~cm}$ od osi wiązki. Dawka w punkcie pomiarowym $10 \mathrm{~cm}$ od CAX wynosiła 2,345 Gy a $30 \mathrm{~cm}$ od CAX o,258 Gy. Nie zaobserwowano istotnej różnicy w dawce pomiędzy punktami pomiarowymi rozmieszczonymi na $30 \mathrm{~cm}$ i $40 \mathrm{~cm}$ od osi wiązki. Dawka zmierzona w odległości $40 \mathrm{~cm}$ od osi wiązki, na głębokości $5 \mathrm{~cm}$ wynosiła blisko 0,5\% dawki w CAX i była wyższa niż dla głębokości $2 \mathrm{~cm}$.

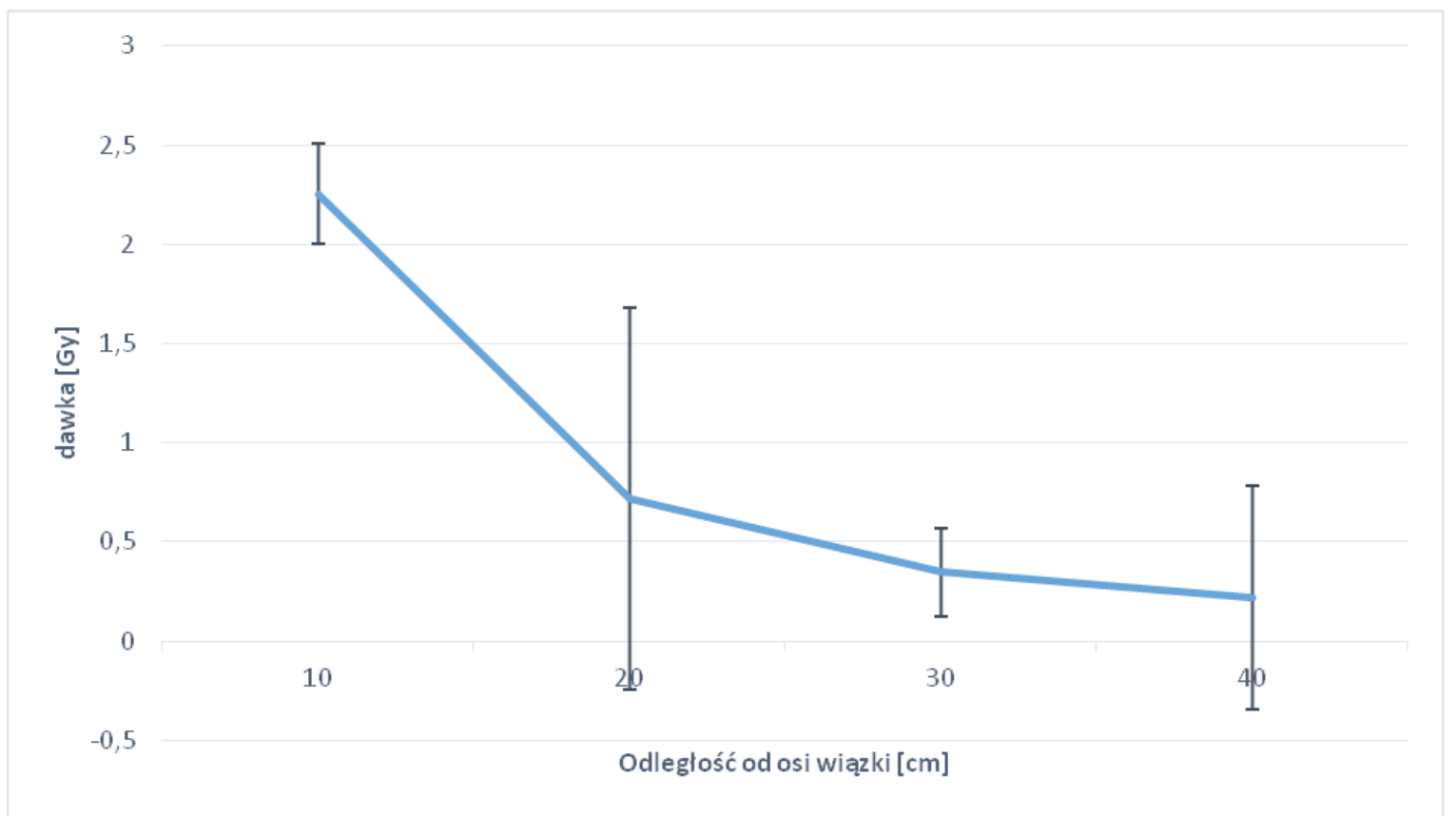

Rycina 5. Zleżność rozkładu dawki od odległości od osi wiązki na głębokości $8 \mathrm{~cm} \mathrm{w}$ fantomie wodnym 


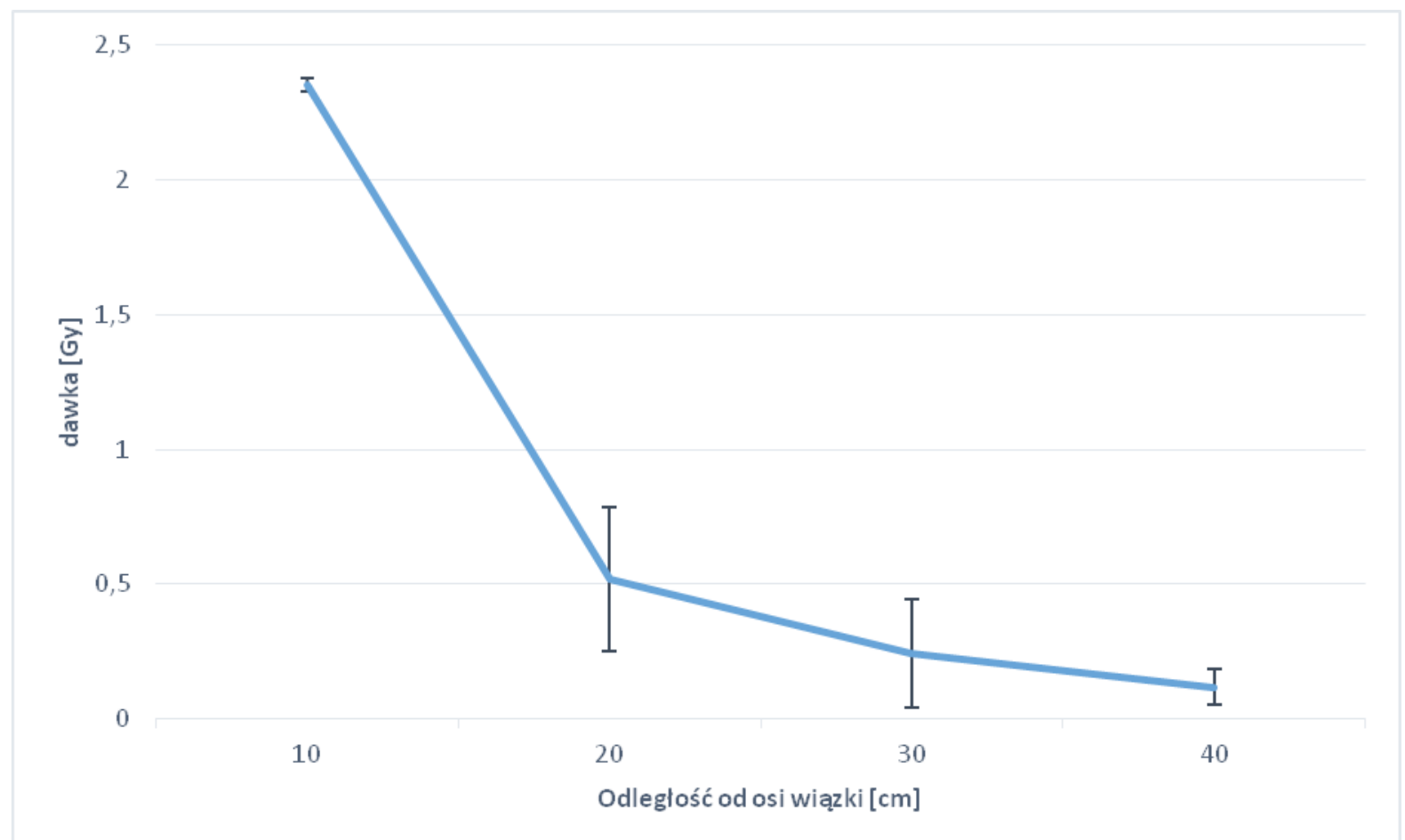

Rycina 6. Zleżność rozkładu dawki od odległości od osi wiązki na głębokości $15 \mathrm{~cm}$ w fantomie wodnym.

Wyniki pomiaru dawek dla głębokości $8 \mathrm{~cm}$ i $15 \mathrm{~cm}$ ukazywały podobną tendencję jak wyżej prezentowane wyniki. Dla głębokości $8 \mathrm{~cm}$, dawka w najodleglejszym punkcie wynosiła 10\% dawki w odległości $10 \mathrm{~cm}$ i o,3\% dawki w CAX. W przypadku głębokości $15 \mathrm{~cm}, 40 \mathrm{~cm}$ od CAX dawka stanowiła 5\% dawki w punkcie $10 \mathrm{~cm}$ od osi i $0,15 \%$ dawki w CAX.

\section{Dyskusja}

Oszacowanie niskich dawek stanowi ważny aspekt dozymetryczny i jest przedmiotem wielu badań. Pomiary przeprowadzane są w fantomach wodnych, fantomach antropomorficznych bądź innych fantomach projektowanych specjalnie na potrzeby badań [11,12]. Problemem podczas pomiaru jest dobór odpowiedniego detektora, który byłby wrażliwy na bardzo niskie sygnały. Drugim aspektem jest brak wystarczającej wiedzy na temat widma promieniowania rozproszonego i składowych energetycznych wchodzących w jego skład. Dodatkowo możliwość kalkulacji dawki przez komercyjne systemy planowania leczenia w obszarach odległych od objętości guza jest bardzo ograniczona. Siji Cyraic i współpracownicy [5] w swojej publikacji wykazali, że systemy planowania leczenia , charakteryzują się dużą niedokładnością w obliczaniu dawki przy krawędzi pola, która sięga 5\% i wzrasta wraz z odległością nawet do 20\%. Brak możliwości dokładnego obliczenia dawki poza obszarem leczonym jest szczególnie niekorzystny, gdy guz zlokalizowany jest blisko ważnych życiowo narządów wrażliwych na promieniowanie (np. rdzeń kręgowy, gonady), ale także gdy radioterapii poddawane są osoby młode bądź w przypadku powtórnego napromieniania.

W prezentowanym badaniu, autorzy obliczyli dawkę zadaną 76 Gy, która symuluje dawkę terapeutyczną stosowaną podczas dwuetapowego napromienia raka prostaty. Na podstawie anatomii rzeczywistych pacjentów określono głębokości pomiarowe, które odpowiadały zróżnicowanemu umiejscowieniu narządów krytycznych w ciele człowieka (nerw wzrokowy, rdzeń). Autorzy ze względu na techniczne ograniczenia fantomu zaprezentowali badanie, w którym uwzględniono tylko jedno otwarte pole napromieniania. Zaawansowane, wielopolowe techniki napromieniania i ich wpływ na dawkę w narządach odległych od objętości leczonej zostały zaprezentowane we wcześniejszym badaniu autorów [8].

D.S. Sharma i współpracownicy [13], wykazali, że zwiększona ilość jednostek monitorowych (ang. MU Monitor Units) stosowana w technice IMRT w porównaniu z techniką 3DCRT dla tej samej dawki frakcyjnej, prowadzi do zwiększenia dawki w tkankach poza polem terapeutycznym. Dawka peryferyjna dla energii 
15MV jest silnie zależna od odległości od osi wiązki i zmienia się wraz z głębokością. Dawki zmierzone dla każdego dystansu i każdej głębokości wykazują tendencję spadkową wraz ze wzrostem ich odległości od osi wiązki. Zaobserwowany został gwałtowny spadek dawek między $10 \mathrm{~cm}$ a $20 \mathrm{~cm}$ od osi wiązki natomiast dawki dla odległości $30 \mathrm{~cm}$ i $40 \mathrm{~cm}$ od CAX dla każdej głębokości nie różniły się znacząco.

Zaprezentowane przez autorów pomiary metodą termoluminescencji pokazują dobra zgodność z pomiarami wykonanymi komorą jonizacyjną i detektorami MOSFET przez Annamalai i Velayudham [14].

Niestety, nadal nie istnieją metody pozwalające w klinicznych warunkach zmierzyć dawkę, jaką otrzymuje pacjent podczas leczenia w obszarach odległych od guza. Stosowane dotychczasowe metody pomiarowe nie pozwalają na zmierzenie w warunkach klinicznych dawki, jaką otrzymują podczas radioterapii obszary poza polem napromieniania.

\section{Podsumowanie}

Kalkulacja dawki poza obszarem leczonym stanowi poważny problem dozymetryczny. Temat niskich dawek jest zagadnieniem bardzo często poruszanym w literaturze, szczególnie gdy rozważania dotyczą indukcji nowotworów wtórnych. Badania dowodzą, że dawki rzędu kilku mGy, mogą powodować istotne efekty biologiczne, co ukazuje zasadność powyższych pomiarów. Z powyższej pracy wysuwają się dwa zasadnicze wnioski:

- detektory termoluminescencyjne są dobrym narzędziem do pomiaru niskich dawek, poza obszarem tarczowym

- dawki zmierzone w punktach odległych od promieniowania, maleją wraz z dystansem od osi wiązki i zmienią się wraz z głębokością pomiaru.

\section{Konflikt interesu/ Conflict of interest}

Nie występuje / None

\section{Finansowanie/ Financial suport}

Badanie zostało sfinansowane ze środków na podstawie grantu nr 18/2014(77) realizowanego w Wielkopolskim Centrum Onkologii.

\section{Etyka/ Ethics}

Treści przedstawione w artykule są zgodne z zasadami Deklaracji Helsińskiej, dyrektywami EU oraz ujednoliconymi wymaganiami dla czasopism biomedycznych.

\section{Piśmiennictwo / References}

[1] Taylor ML, Kron T, Franich RD (2011) Assessment of out-of-field doses in radiotherapy of brain lesions in children. Int J Radiat Oncol Biol Phys, 79(3):927-33.

[2] Klein EE, Maserang B, Wood R, Mansur D (2006) Peripheral doses from pediatric IMRT. Med Phys, 33(7):2525-31.

[3] Howell RM, Scarboro SB, Kry SF, Yaldo DZ (2010)Accuracy of out-of-field dose calculations by a commercial treat-ment planning system. Phys Med Biol, 55(23):6999-7008.

[4] Jang SY, Liu HH, Mohan R (2008) Underestimation of low-dose radiation in treatment planning of intensity-modulated radiotherapy. Int J Radiat Oncol Biol Phys, 71(5): 1537-46.

[5] Siji Cyriac, M.M. Musthafa, R. Ganapathi Raman, K. Abdul Haneefa, Saju Bhasi (2015). Out-of-field photon dosimetry study between 3-D conformal and intensity modulated radiation therapy in the management of prostate cancer. International Journal of Radiation Research, Volume 
13, No 2

[6] Xu X G, Bednarz B and Paganetti H (2008). A review of dosimetry studies on external-beam radiation treatment with respect to second cancer induction. Phys. Med. Biol. 53 193-241

[7] Newhauser Wand Durante M (2011). Assessing the risk of second malignancies after modern radiotherapy. Nature Rev.Cancer 11 1-11

[8] A. Kowalik, W. Jackowiak, J. Malicki, M. Skórska, M. Adamczyk, E. Konstanty, T. Piotrowski, K. Polaczek-Grelik

Measurements of doses from photon beam irradiation and scattered neutrons in an anthropomorphic phantom model of prostate cancer: a comparison between 3DCRT, IMRT and tomotherapy, NUKLEONIKA 2017;62(1):29-35 doi: 10.1515/nuka-2017-0005

[9] M. Rafi Uddina, M. Jahangir Alamb and G. U. Ahmada (2003). Measurement of dose outside the irradiated volume by using locally fabricated water phantom. Bangladesh Journal of Medical Physics Vol. 2.

[10] Kaderka R, Schardt D, Durante M, Berger T, Ramm U, Licher J, La Tessa C (2017).Out-of-field dose measurements in a water phantom using different radiotherapy modalities. Phys Med Biol. 57(16):505974 .

[11] Purdy J (2008). Dose to normal tissue outside theradiation therapy patients treated volume: a review of different radiation therapy techniques. Health Phys,95(5): 666-676.

[12] Ruben JD, Lancaster CN, Jones P, Smith RL (2011.) A comparison of out-of-field dose and its constituent com-ponents for intensity-modulated radiation therapy versus conformal radiation therapy: implications for carcinogenesis. Int J Radiat Oncol Biol Phys,81:1458-1464.

[13] Sharma D S, Animesh, Deshpande S S et al. (2006). Peripheral dose from uniform dynamic multileaf collimation fields: implications for sliding window intensity-modulated radiotherapy. Br J Radiol; 79: $331-5$.

[14] Anamalai G., Velayudham R.(2009). Comparison of peripheral dose measurements using ionization chamber and MOSFET detector, Rep Pract Oncol Radiother. Volume 14, Issue 5, Pages 176-183. 